\title{
$\operatorname{Pd}(\mathrm{OAc})_{2} /(S)-\mathrm{P}-\mathrm{PHOS}$ 催化的丙烯与 CO 交替共聚合 成手性功能高分子
}

\author{
王来来，贾小静，万博 \\ 中国科学院兰州化学物理研究所羰基合成与选择氧化国家重点实验室, 甘肃兰州 730000
}

\begin{abstract}
摘要：以丙烯和 $\mathrm{CO}$ 为原料, $\mathrm{Pd}(\mathrm{OAc})_{2} /(S)$-P-PHOS 为手性催化剂, 在有机溶剂中, 经不对称交替共聚反应合成了手性功能高分子 聚酮. 当过量的还原剂 $\mathrm{LiAlH}_{4}$ 和 $\mathrm{NaBH}_{4}$ 分别还原聚酮时, 手性聚醇产率达 $90 \%$; 当 $\mathrm{NaBH}_{4} /$ 羊基摩尔比分别为 $0.5,1$ 和 2 , 紫外光 谱 (200 400 nm) 检测证明, 手性聚酮中羰基的 29\%, $71 \%$ 和 $81 \%$ 分别被还原; 使用过量的还原剂 $\mathrm{BH}_{3}$. THF 时, 手性聚酮中羰基只 能部分被还原. 手性聚醇的数均分子量比手性聚酮的低,产物手性聚醇的摩尔旋光度随还原反应条件而变化.
\end{abstract}

关键词：醋酸钯；手性双膦配体；丙烯；一氧化碳；手性聚酮；还原剂；手性聚醇

中图分类号: 0643

文献标识码: A

\section{Synthesis of Chiral Functionalized Polymers by Alternating Copolymerization of Propene and CO Using the $\mathrm{Pd}(\mathrm{OAc})_{2} /(S)$-P-PHOS Catalyst}

\author{
WANG Lailai*, JIA Xiaojing, WAN Bo \\ State Key Laboratory for Oxo Synthesis and Selective Oxidation, Lanzhou Institute of Chemical Physics, \\ Chinese Academy of Sciences, Lanzhou 730000, Gansu, China
}

\begin{abstract}
Pd}(\mathrm{OAc})_{2}$ (palladium acetate)/(S)-P-PHOS ((S)-2,2',6,6'-tetramethoxy-4,4'-bis(diphenyl)phosphino)-3,3'-bipyridine) catalysis systems were applied to the alternating copolymerization of propene and $\mathrm{CO}$ in organic solvents to synthesize chiral polyketones. The diastereoselective reduction of a chiral polyketone using excess $\mathrm{LiAlH}_{4}$ (lithium aluminum hydride) and $\mathrm{NaBH}_{4}$ (sodium borohydride) as reducing agents gave a new class of optically active polyalcohol and the product yield was more than $90 \%$. In the presence of various amounts of $\mathrm{NaBH}_{4}\left(\mathrm{NaBH}_{4} /\right.$ carbonyl molar ratio of $0.5,1$, and 2), quantitative measurements of the intensity of the carbonyl absorbance at $200-400$ $\mathrm{nm}$ in the UV (ultraviolet) spectrum showed a reduction of $29 \%, 71 \%$, and $81 \%$, respectively, for the carbonyl groups. The use of excess $\mathrm{BH}_{3}$. THF (borane tetrahydrofuran complex) as a reducing agent resulted in a partial reduction of the carbonyl groups of the chiral polyketone. The molecular weight of the product was lower than that of the chiral polyketone and the molar optical rotations of the product varied with the reductive conditions.
\end{abstract}

Key words: palladium acetate; chiral diphosphous ligand; propene; carbon monoxide; chiral polyketone; reducing agent; chiral polyalcohol

The alternating copolymerization of olefins and $\mathrm{CO}$ has attracted considerable attention from both academia and industry over the last few decades [1]. Initially, the reaction occurred in the presence of a radical initiator using ethylene as a starting material. Several polymers incorporating a variety of heteroatom functionalities have been synthesized and the product $\mathrm{C}_{2} \mathrm{H}_{4} / \mathrm{CO}$ ratio has been found to be more than 1 [2]. The obtained products exhibit engineering plastic properties. In the 1980 s, a class of highly active palladium catalysts for this reaction (Scheme 1) were reported [3,4]. A terpolymer derived from ethene, propene, and $\mathrm{CO}$ became commercially available under the trade name Carilon. The alternating copolymers (olefin/ $\mathrm{CO}=1$ ) have the highest possible concentration of reactive carbonyl groups, which can be chemically modified to new functional groups such as hydroxyl, cyano, amino, etc. Polyketones are also excellent starting materials for other classes of polymers such as polyalcohols [2], polyamines [5], polyoximes [2,6-8], poly-

Received 30 June 2010. Accepted 17 September 2010

*Corresponding author. Tel: +86-931-4968161; Fax: +86-931-4968129; E-mail: wll@licp.cas.cn

Foundation item: Supported by the National Natural Science Foundation of China $(20343005,20473107,20673130,20773147)$

English edition available online at ScienceDirect (http://www.sciencedirect.com/science/journal/18722067). 

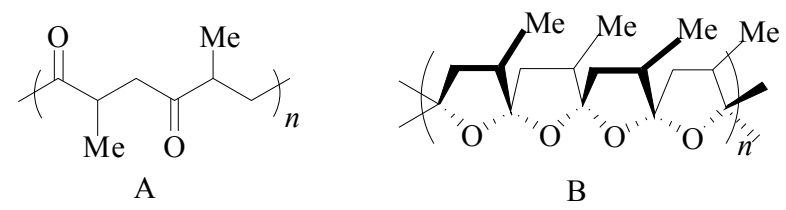

Scheme 1. Ketone and spiroketal repeat units of a polyketone. A: poly(1-oxo-2-methyltrimethlyene); B: poly[spiro-2,5-(3-methyltetrohedrofuran)].

acetals [9], polythiophene [10], etc.

Recently, a few examples of enantioselective copolymerization using either in situ or preformed Pd complexes modified by chiral phosphorus ligands [11] have been shown to give high regioregularity and an almost completely isotactic polyketone. Mixtures of stereoregular copolymers of opposite chirality have been shown to exhibit curious melting behavior [12]. Jiang et al. [13] reported that $\left[\mathrm{Pd}(\mathrm{Me}-\mathrm{DUPHOS})(\mathrm{MeCN})_{2}\right]\left(\mathrm{BF}_{4}\right)_{2}$ [Me-DUPHOS $=1,2$ bis(2,5-dimethylphos phorlano)benzene] (Scheme 2) is an effective catalyst for enantioselective alternating copolymerization, and the product was found to be an excellent starting material for the synthesis of chiral polyalcohols. For example, the complete reduction of the copolymer resulted in the formation of a novel, chiral polyalcohol using $\mathrm{LiAlH}_{4}$ as a reducing agent. Recently, chiral polyketone has been synthesized using the catalyst $[\mathrm{Pd}((R, S)$-BINAPHOS $)(\mathrm{Me})$ $\left.\left(\mathrm{CH}_{3} \mathrm{CN}\right)\right] \quad\left[\mathrm{BAr}_{4}\right](\mathrm{Ar}=3,5$-bis(trifluoromethyl)phenyl) (Scheme 2). Reduction of the product using tetrabutylammonium borohydride as a reducing agent gave the chiral polyalcohol in quantitative yield. The absolute configuration of the chiral centers was determined by comparison with four diastereomers of 3-methyl-2,5-hexanediol [14].
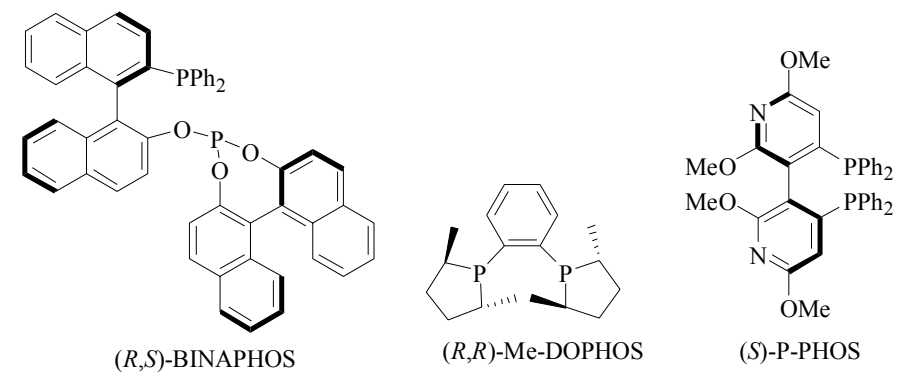

Scheme 2. Chiral ligands used in asymmetric alternating copolymerization.

In this work, we used the $\mathrm{Pd}(\mathrm{OAc})_{2} /(S)$-P-PHOS catalyst (Scheme 2) for the alternating copolymerization of propene and $\mathrm{CO}$ to synthesize chiral polyketones. The chiral ligand (S)-P-PHOS was kindly supplied by the Hong Kong Polytechnic University. The novel chiral polyalcohol was synthesized by the reduction of these ketones using $\mathrm{LiAlH}_{4}$, $\mathrm{NaBH}_{4}$, and $\mathrm{BH}_{3} \cdot \mathrm{THF}$ as reducing agents. ${ }^{1} \mathrm{H}$ NMR (nuclear magnetic resonance), ${ }^{13} \mathrm{C}$ NMR, and IR (infrared spectroscopy) were consistent with the data expected for these compounds. The effect of various concentrations of $\mathrm{NaBH}_{4}$ on the reduction of carbonyl groups has been investigated by UV. The molar optical rotations of the chiral polyalcohols varied with the reduction conditions.

\section{Experimental}

\subsection{Copolymerization of propene and CO [15,16,17]}

A mixture of $\mathrm{Pd}(\mathrm{OAc})_{2}(10.3 \mathrm{mg}, 0.046 \mathrm{mmol})$, (S)-P-PHOS (29.6 mg, $0.046 \mathrm{mmol})$, and $\mathrm{BF}_{3} \cdot \mathrm{Et}_{2} \mathrm{O}(0.051$ mmol) was stirred magnetically in $\mathrm{CH}_{2} \mathrm{Cl}_{2} / \mathrm{CH}_{3} \mathrm{OH}(25: 2$, $\mathrm{v} / \mathrm{v}$ ) under nitrogen for $1.5 \mathrm{~h}$ at room temperature. The solution was transferred to a $100 \mathrm{ml}$ stainless steel reactor under nitrogen and the reactor was then charged with $35 \mathrm{~g}$ of propene in a cold bath at $0{ }^{\circ} \mathrm{C}$ and under 4.0 $\mathrm{MPa} \mathrm{CO}$. The re- action mixture was stirred at $50{ }^{\circ} \mathrm{C}$ for $24 \mathrm{~h}$. At the end of the reaction the reactor was cooled to room temperature and the unreacted gases were released. To remove the metal catalyst, the suspension was passed through a short silica gel column using $\mathrm{CH}_{2} \mathrm{Cl}_{2}$ as the eluant. The copolymer ( $3.36 \mathrm{~g}$ ) with productivities as high as $28.6 \mathrm{~g}$ of polyketone (per gram of Pd per hour) was obtained after the complete removal of the solvent. $[\Phi]_{D}^{20}=0.35$ (c 0.5 , THF, JASCOJ-20C); IR $\left(\mathrm{cm}^{-1}\right)$ : 2964, 2931, 2873, $1738(\mathrm{C}=\mathrm{O})$, $1710(\mathrm{C}=\mathrm{O}), 1093,1030$, and $802(\mathrm{C}-\mathrm{O}-\mathrm{C}$, spiroketal group); ${ }^{1} \mathrm{H}$ NMR (Bruker IFS 120HR, $400 \mathrm{MHz}, \mathrm{CDCl}_{3}$ ): $\delta$ 5.67-5.61 (1H, m), 3.50, 3.22-2.67 (-CH-), 2.63-1.70 $\left(-\mathrm{CH}_{2}-\right), 1.63-0.75\left(-\mathrm{CH}_{3}\right) ;{ }^{13} \mathrm{C}$ NMR (Bruker AM125, 125 $\left.\mathrm{MHz}, \mathrm{CDCl}_{3}\right): \delta 211(\mathrm{C}=\mathrm{O}), 207(\mathrm{C}=\mathrm{O}), 175\left(\mathrm{CH}_{3} \mathrm{O}-\right), 115$, $113,51\left(-\mathrm{CH}_{2}-\right), 48-45(-\mathrm{CH}-), 16\left(-\mathrm{CH}_{3}\right)$.

\subsection{Reduction of the polyketone using $\mathrm{LiAlH}_{4}, \mathrm{NaBH}_{4}$, and $\mathrm{BH}_{3} \cdot \mathrm{THF}$}

When using $\mathrm{LiAlH}_{4}$ as the reducing agent, to THF (30 $\mathrm{ml}$ ) containing $0.321 \mathrm{~g}$ of polyketone was added $0.500 \mathrm{~g}$ of $\mathrm{LiAlH}_{4}$ and the resulting mixture was stirred at $60{ }^{\circ} \mathrm{C}$ for 12 $\mathrm{h}$. At the end of the reaction the solution was cooled to room temperature. The cold solution was left for $1 \mathrm{~h}$ and then enough distilled water was added to decompose the $\mathrm{LiAlH}_{4}$ 
residue. Following the removal of the aqueous layer, the separated organic layer was dried over anhydrous $\mathrm{MgSO}_{4}$. The organic layer was passed through a short silica gel column using THF as the eluant and the eluate was concentrated under reduced pressure to afford the polyalcohol as a white solid $0.296 \mathrm{~g}$. Yield, 92.3\%; $[\Phi]_{D}^{20}=+2.33$ (c 0.5, THF); IR $\left(\mathrm{cm}^{-1}\right): 3365(-\mathrm{OH}), 1183,1089$, and 862 (C-O-C, spiroketal group); ${ }^{1} \mathrm{H}$ NMR $\left(\mathrm{CD}_{3} \mathrm{Cl}\right): \delta 5.12(1 \mathrm{H}$, s), 3.90-3.25 (1H, br), 2.12-1.74 (2H, br), 1.40-1.12 (1H, $\mathrm{m}, \mathrm{br}), 0.83(3 \mathrm{H}, \mathrm{m}) ;{ }^{13} \mathrm{C} \mathrm{NMR}\left(\mathrm{CD}_{3} \mathrm{Cl}\right): \delta 66,62,37,35$, $30,28,22,18,17,15$.

When using $\mathrm{NaBH}_{4}$ as the reducing agent in procedure 1, to THF ( $30 \mathrm{ml}$ ) containing $0.321 \mathrm{~g}$ of polyketone was added $0.500 \mathrm{~g}$ of $\mathrm{NaBH}_{4}$ and the resulting mixture was stirred using ultrasonication at $60{ }^{\circ} \mathrm{C}$ for $1 \mathrm{~h}$ and at $50{ }^{\circ} \mathrm{C}$ for $5 \mathrm{~h}$. The reaction was quenched by the addition of an adequate amount of distilled water. Following the removal of the aqueous layer the separated organic layer was dried over anhydrous $\mathrm{MgSO}_{4}$. The organic layer was passed through a short silica gel column using THF as the eluant and the eluate was concentrated under reduced pressure to afford the polyalcohol as a white solid (0.317 g). Yield, 98.7\%; $[\Phi]_{D}^{20}=-0.75$ (c 0.5, THF); IR $\left(\mathrm{cm}^{-1}\right): 3377-3357(-\mathrm{OH})$, 1193, 1080, and 812 (C-O-C, spiroketal group); ${ }^{1} \mathrm{H}$ NMR $\left(\mathrm{CD}_{3} \mathrm{Cl}\right): \delta 5.10(1 \mathrm{H}, \mathrm{s}), 3.96-3.64(1 \mathrm{H}, \mathrm{br}), 2.04-1.45(2 \mathrm{H}$, br), $1.40-1.20(1 \mathrm{H}, \mathrm{br}), 0.85(3 \mathrm{H}, \mathrm{m}) ;{ }^{13} \mathrm{C} \mathrm{NMR}\left(\mathrm{CD}_{3} \mathrm{Cl}\right): \delta$ $67(\mathrm{C}-\mathrm{OH}), 62(\mathrm{C}-\mathrm{OH}), 38,32,30,28,22,18,17,14$.

In procedure 2 , to THF $(30 \mathrm{ml})$ containing $0.200 \mathrm{~g}$ of polyketone was added various amounts of $\mathrm{NaBH}_{4}$ $\left(\mathrm{NaBH}_{4} /\right.$ carbonyl molar ratio of 2,1 , and 0.5$)$ and the resulting mixtures were stirred at room temperature for $24 \mathrm{~h}$. The reaction was quenched by the addition of an adequate amount of distilled water. Following the removal of the aqueous layer the separated organic layer was dried over anhydrous $\mathrm{MgSO}_{4}$. The organic layer was passed through a short silica gel column using THF as the eluant and the eluate was concentrated under reduced pressure to afford the polyalcohol as a white solid $(0.113,0.117$, and $0.160 \mathrm{~g}$, respectively) with yield of $56.5 \%, 58.7 \%$, and $80.0 \%$, respectively. Quantitative UV analyses (HP 8453 UV-Vis spectrometer) at $200-400 \mathrm{~nm}$ in a $1-\mathrm{cm}$ fused quartz cells were performed. Solutions of polyketones and polyalcohols in chloroform were irradiated. Chloroform was used as a control blank.

When using $\mathrm{BH}_{3} \cdot$ THF as the reducing agent, to THF (15 $\mathrm{ml}$ ) containing $0.321 \mathrm{~g}$ of polyketone was added $8 \mathrm{ml}$ of $\mathrm{BH}_{3} \cdot \mathrm{THF}$ under a $\mathrm{N}_{2}$ atmosphere and the resulting mixture was stirred at $0{ }^{\circ} \mathrm{C}$ for $1 \mathrm{~h}$. The reaction was quenched by the addition of an adequate amount of distilled water. Following the removal of the aqueous layer the separated organic layer was dried over anhydrous $\mathrm{MgSO}_{4}$. The organic layer was passed through a short silica gel column using
THF as the eluant and the eluate was concentrated under reduced pressure to afford the polyalcohol as a white solid (0.313 g). Yield, 97.3\%; [ $\Phi]_{D}^{20}=+2.57$ (c 0.5, THF); IR $\left(\mathrm{cm}^{-1}\right): 3482(-\mathrm{OH}), 1740(\mathrm{C}=\mathrm{O}), 1103,1030$, and 832 $\left(\mathrm{C}-\mathrm{O}-\mathrm{C}\right.$, spiroketal group); ${ }^{1} \mathrm{H}$ NMR $\left(\mathrm{CD}_{3} \mathrm{Cl}\right): \delta 5.23(1 \mathrm{H}$, s), 3.95-3.61 (1H, br), 1.83-1.52 (2H, br), 1.10-1.06 (1H, br), $0.83(3 \mathrm{H}, \mathrm{m}) ;{ }^{13} \mathrm{C} \mathrm{NMR}\left(\mathrm{CD}_{3} \mathrm{Cl}\right): \delta 212(\mathrm{C}=\mathrm{O}), 208$ $(\mathrm{C}=\mathrm{O}), 67,62,44,32,18,17,15,13$.

\section{Results and discussion}

\section{$2.1{ }^{13} \mathrm{C}$ NMR of the chiral polyketone and polyalcohol}

The weak resonances at $\delta=211$ and 207 in the ${ }^{13} \mathrm{C}$ NMR spectrum of the chiral polyketone indicated the presence of keto groups in the polymers. The resonance at 175 was attributed to the ester end group carbon $\left(\mathrm{CH}_{3} \mathrm{O}-\right)$ and the resonances at 115 and 113 were attributed to the ketal carbons of the spiroketal repeating units in the polymer backbone (Scheme 1). The resonances at $\delta=51-48$ were attributed to the $-\mathrm{CH}_{2}-$ and $-\mathrm{CH}-$ of the spiroketal repeating units and the resonances at 45-16 were attributed to the $-\mathrm{CH}_{2}-,-\mathrm{CH}-$, and $-\mathrm{CH}_{3}$ of the $-\mathrm{CH}\left(\mathrm{CH}_{3}\right) \mathrm{CH}_{2} \mathrm{C}(\mathrm{O})-$ units in the copolymer.

The ${ }^{13} \mathrm{C}$ NMR spectra of the polymer produced using excess $\mathrm{NaBH}_{4}$ did not show any absorption at $\delta=211$ or 207, which clearly indicated that the carbonyl groups of the polyketone were quantitatively reduced to alcohols. The ${ }^{13} \mathrm{C}$ NMR absorptions of the polymer as a result of the $-\mathrm{CH}-$ (adjacent to $-\mathrm{OH}),-\mathrm{CH}-$ (adjacent to $\left.-\mathrm{CH}_{3}\right),-\mathrm{CH}_{2}-$, and $-\mathrm{CH}_{3}$ groups were observed at $\delta=67,62$, and 38-14, respectively. The polymer obtained using $\mathrm{NaBH}_{4}$ as a reductant showed broad ${ }^{1} \mathrm{H}$ NMR peaks. The resonance at 3.96-3.64 was due to the hydrogens on the carbons bearing the alcohol functionality and the resonance at 2.04-0.71 was attributed to the $-\mathrm{CH}\left(\mathrm{CH}_{3}\right) \mathrm{CH}_{2} \mathrm{C}(\mathrm{OH})-$ units in the copolymer.

\subsection{IR of the chiral polyalcohol}

The IR spectrum of the polyketone showed absorbances at 2964,2931 , and $2873 \mathrm{~cm}^{-1}$ because of the $-\mathrm{CH}-,-\mathrm{CH}_{2}-$, and $-\mathrm{CH}_{3}$ groups, respectively. Moderate carbonyl absorbances at 1738 and $1710 \mathrm{~cm}^{-1}$ and strong $\mathrm{C}-\mathrm{O}-\mathrm{C}$ bands at 1093, 1030, and $802 \mathrm{~cm}^{-1}$ were also observed for the ketone and the spiroketal repeating units in the polymer backbones. The polymers obtained using excess $\mathrm{LiAlH}_{4}$ and $\mathrm{NaBH}_{4}$ showed a broad IR band at $3377-3357 \mathrm{~cm}^{-1}$ because of the hydroxyl groups. The absence of IR absorptions at 1738 and $1710 \mathrm{~cm}^{-1}$ indicated a complete carbonyl to alcohol reduction. The IR spectra of the new polymer obtained using excess $\mathrm{BH}_{3}$.THF showed a band at $3482 \mathrm{~cm}^{-1}$ and this was due 
to hydroxyl groups. An additional IR absorption at 1740 $\mathrm{cm}^{-1}$ indicated the presence of unreduced carbonyl groups in the product. Therefore, the IR results of the product showed that the carbonyl groups of the chiral polyketone were partially reduced by the excess $\mathrm{BH}_{3} \cdot \mathrm{THF}$.

\subsection{UV spectra of the chiral polyalcohol}

It was possible to follow the extent of reduction quantitatively by monitoring the intensity of the carbonyl UV absorbance at 200-400 nm. Typical UV curves for the copolymers in chloroform are shown in Fig. 1. The maximum absorption found at $248 \mathrm{~nm}$ is similar to that for carbonyls in simple ketones. Some of the copolymers showed an absorption in the region of $350 \mathrm{~nm}$. Under our experimental conditions and using various amounts of $\mathrm{NaBH}_{4}\left(\mathrm{NaBH}_{4} /\right.$ carbonyl molar ratio of $0.5,1$, and 2 ) at ambient temperature resulted in the reduction of $29 \%, 71 \%$, and $81 \%$ of the carbonyl groups (Fig. 1).

\subsection{Molar optical rotations of the chiral polyalcohol}

Molecular weight measurements of the polymers were performed with water GPCV2000 liquid/gel permeation chromatography using ODS2 Hypersil columns and a VWDA detector. Catechol and polystyrene standards were used. The molecular weight and molar optical rotations of the chiral polyalcohol are shown in Table 1 . We found that the molecular weight of the chiral polyalcohol was lower

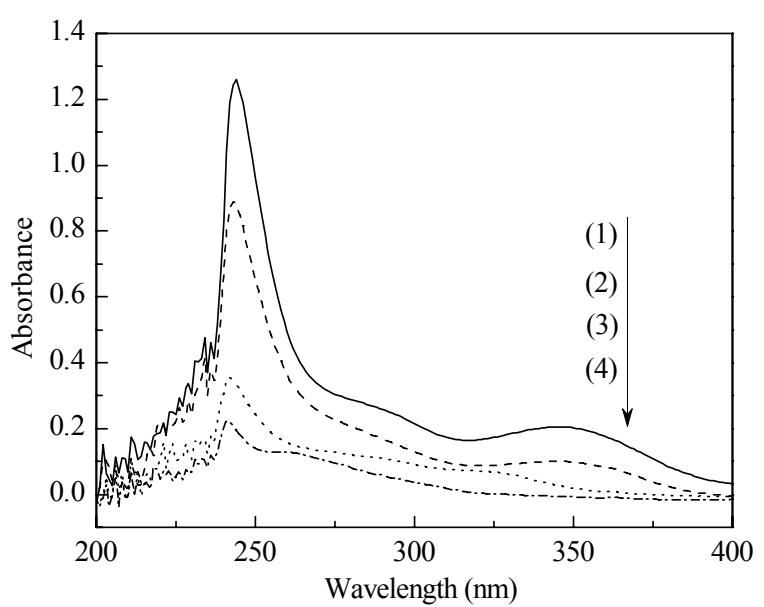

Fig. 1. UV curves for a chiral polyketone and polyalcohol. (1) Chiral polyketone; (2)-(4) The product of reduction in $\mathrm{NaBH}_{4} /$ carbonyl molar ratio of $0.5,1$, and 2 , respectively.

than that of the chiral polyketone. These results are consistent with that of a similar chemically modified polymer reported by Refs. [18,19]. The polyalcohol obtained after $\mathrm{NaBH}_{4}$ reduction had the same direction of optical rotation as the chiral polyketone [15-17] (Table 1, entries 2, 4, 5). However, $\mathrm{LiAlH}_{4}$ and $\mathrm{BH}_{3} \cdot \mathrm{THF}$ reduction gave a product with an opposite direction of optical rotation for the polyalcohol and the degree of molar optical rotation for the chiral polyalcohol obtained after $\mathrm{NaBH}_{4}$ reduction remained smaller than that after $\mathrm{LiAlH}_{4}$ and $\mathrm{BH}_{3} \cdot \mathrm{THF}$ reduction (Table 1 , entries 1-3).

Table 1 Effects of the reducing agents $\mathrm{LiAlH}_{4}, \mathrm{NaBH}_{4}$, and $\mathrm{BH}_{3} \cdot \mathrm{THF}$ on the reduction of chiral polyketones

\begin{tabular}{cccccccc}
\hline Entry & Reducer & Reducer/carbonyl molar ratio & Time $(\mathrm{h})$ & Temperature $\left({ }^{\circ} \mathrm{C}\right)$ & Yield $(\%)$ & $M_{\mathrm{n}} / 10^{-3}\left(M_{\mathrm{w}} / M_{\mathrm{n}}\right)$ & {$[\Phi]_{D}^{20}$} \\
\hline 1 & $\mathrm{LiAlH}_{4}$ & 3 & 12 & 60 & 92.3 & $2.1(1.2)$ & +2.33 \\
2 & $\mathrm{NaBH}_{4}$ & 3 & 6 & 50 & 98.7 & $1.5(1.1)$ & -0.75 \\
3 & $\mathrm{BH}_{3} \cdot \mathrm{THF}$ & $>10$ & 1 & 0 & 97.3 & $2.0(1.4)$ & +2.57 \\
4 & $\mathrm{NaBH}_{4}$ & 2 & 24 & 20 & 56.5 & $1.3(1.1)$ & -0.45 \\
5 & $\mathrm{NaBH}_{4}$ & 0.5 & 24 & 20 & 80.0 & $1.8(1.1)$ & -0.06 \\
\hline
\end{tabular}

$M_{\mathrm{w}}$ is the weight average molecular weight, $M_{\mathrm{n}}$ is the number average molecular weight, and the ratio $M_{\mathrm{w}} / M_{\mathrm{n}}$ is referred to as polydispersity. For polyketone, $M_{\mathrm{w}}=3.1 \times 10^{3}, M_{\mathrm{n}}=3.0 \times 10^{3}, M_{\mathrm{w}} / M_{\mathrm{n}}=1.0,[\Phi]_{D}^{20}=-0.35$.

The stereochemistry of the reduction products of selected ketones by a variety of main group metal hydrides has been investigated under identical conditions. The stereochemistry of reduction by complex aluminohydrides has been shown to be dependent on the nature of the cation. A comparison between $\mathrm{LiAlH}_{4}$ and $\mathrm{LiBH}_{4}$ as reducing agents for ketones showed that $\mathrm{LiBH}_{4}$ was less sensitive to steric interactions [20]. When various amounts of $\mathrm{NaBH}_{4}$ were used different degrees of optical rotation were found for the polyalcohol (Table 1, entries 4 and 5). We propose that reducing agents approach from the least sterically hindered side of the chiral polyketone to give a new asymmetric $\alpha$-carbon atom as shown in Scheme 3. The enantioselectivity of an $\alpha$-carbon atom depends on the absolute configuration of the $\gamma$-stereogenic center of the polyketone backbone while the direction of optical rotation of the products is mainly controlled by the absolute configuration of the $\alpha$ - and $\gamma$ - stereogenic center.

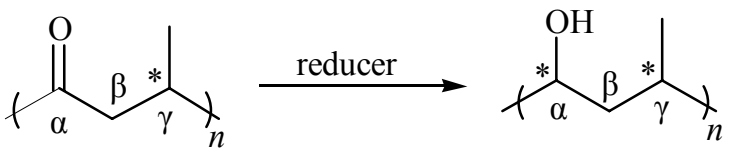

Scheme 3. A chiral polyalcohol derived from a polyketone. 


\section{Conclusions}

Chiral polyketones were synthesized by the alternating copolymerization of propene and $\mathrm{CO}$ using the $\mathrm{Pd}(\mathrm{OAc})_{2} /(S)$-P-PHOS catalyst in $\mathrm{H}_{2} \mathrm{CCl}_{2} / \mathrm{CH}_{3} \mathrm{OH}$. The complete reduction of the carbonyl groups of polyketone using excess $\mathrm{LiAlH}_{4}$ and $\mathrm{NaBH}_{4}$ occurred in THF to afford a new class of chiral polyalcohol and the product yield was more than $90 \%$. When various amounts of $\mathrm{NaBH}_{4}$ $\left(\mathrm{NaBH}_{4} /\right.$ carbonyl molar ratio of $0.5,1$, and 2$)$ were applied, $29 \%, 71 \%$, and $81 \%$ of the carbonyl groups were reduced. The use of excess $\mathrm{BH}_{3}$. THF resulted in the partial reduction of the chiral polyketone. The molecular weight of the chiral polyalcohol was lower than that of the chiral polyketone. The molar optical rotations of the chiral polyalcohols varied with the reductive conditions and the results show that the enantioselectivity of the additional chiral center in the polyalcohol main chain was not extremely high.

Dedicated to Professor Albert S. C. CHAN on the occasion of his 60th birthday.

\section{References}

1 Axet M R, Amoroso F, Bottari G, D'Amorat A, Zangrando E, Faraone F, Drommi D, Saporita M, Carfagna C, Natanti P, Seraglia R, Milani B. Organometallics, 2009, 28: 4464

2 Brubaker M M, Coffman D D, Hoehn H H. J Am Chem Soc,
1952, 74: 1509

3 Ash C E. J Mater Educ, 1994, 16: 1

4 Medema D, Noordam A. Chem Mag, 1995, (3): 127

5 Coffman D D, Hoehn H H, Maynard J T. J Am Chem Soc, 1952, 76: 6394

6 Lu S Y, Paton R M, Green M J, Lucy A R. Eur Polym J, 1996, 32: 1285

7 Sen A. Chemtech, 1986, 16: 48

8 Khansawai P, Paton R M, Reed D. Chem Commun, 1999: 1297

9 Green M J, Lucy A R, Lu S Y, Paton R M. Chem Commun, 1994: 2063

10 Jiang Z Z, Sangganeria S, Sen A. J Polym Sci A, 1994, 32: 841

11 Nakamura A, Ito S, Nozaki K. Chem Rev, 2009, 109: 5215

12 Jiang Z Z, Boyer M T, Sen A. J Am Chem Soc, 1995, 117: 7037

13 Jiang Z Z, Sen A. J Am Chem Soc, 1995, 117: 4455

14 Nozaki K, Kosaka N, Muguruma S. Hiyama T. Macromolecules, 2000, 33: 5340

15 Wang H J, Wang L L, Lam W S, Y u W Y, Chan A S C. Tetrahedron: Asymmetry, 2006, 17: 7

16 Cui Y M, Wang L L, Kwong F Y, Tse M K, Chan A S C. Synlett, 2009, 16: 2696

17 贾小静, 崔玉明, 王来来. 分子催化 (Jia X J, Cui Y M, Wang L L. J Mol Catal (China)), 2008, 22: 408

18 Loan L D, Winslow F H. In: Bovey F A, Winslow F H eds. Macromolecules: An Introduction to Polymer Science. New York: Academic Press, 1979

19 Moore J A. Reactions of Polymers. Boston: D. Reidel, 1973

20 Ashby E C, Boone J R. J Org Chem, 1976, 41: 2890 